\title{
Variability of urea concentration in camel milk in Kazakhstan
}

\author{
Bernard FAYE $^{1 *}$, Gaukhar KonUSPayeva ${ }^{2}$, Gérard LoISEAU $^{1}$ \\ ${ }^{1}$ Centre de Coopération Internationale en Recherche Agronomique pour le Développement, \\ Campus international de Baillarguet TA C/dir B, 34398 Montpellier cedex, France \\ ${ }^{2}$ Kazakh State University Al Farabi, 71 av. Al-Farabi, 050040 Almaty, Kazakhstan
}

Received 12 February 2010 - Revised 4 March 2010 - Accepted 8 March 2010

Published online 18 June 2010

\begin{abstract}
Urea is a part of non-protein nitrogen in milk. The variability of its concentration was never reported in camel milk. The present communication aimed to give some reference values on urea content in camel milk and to explore some interpretable variation factors. In 102 milk samples collected in Kazakhstan, at four seasons of the year, in four distant regions and in different species (Camelius dromedaries, Camelius bactrianus and their hybrids), urea was determined in the raw milk. The mean value of urea concentration was $81.6 \pm 60.4 \mathrm{mg} \cdot \mathrm{L}^{-1}$ with a range of $0-290.5 \mathrm{mg} \cdot \mathrm{L}^{-1}$. The values changed significantly $(P<0.001)$ according to season, the highest concentration being observed in spring when the grass contained the highest soluble nitrogen. The milk urea was positively correlated to the total protein concentration in milk. On average, those values were lower than in cow milk.
\end{abstract}

dromedary / Bactrian camel / milk / urea

摘要 - 哈萨克斯坦骆驼奶中尿素浓度的变化。尿素是乳中非蛋白氮中的一部分。目前尚无 关于尿素在骆驼乳中浓度变化的报道。本文介绍了牦牛乳中尿素浓度的参考值以及影 响浓度变化的可能因素。在哈萨克斯坦采集一年内四个季节的不同地区和不同品种 (单峰 骆驼、双峰骆驼、以及两种骆驼的杂交种) 的 102 个骆驼奶样品, 测定样品中尿素的浓 度。尿素的平均值在 $81.6 \pm 60.4 \mathrm{mg} \cdot \mathrm{L}^{-1}$, 测定值的范围为 $0 \sim 290.5 \mathrm{mg} \cdot \mathrm{L}^{-1}$ 。随着季节的 不同，尿素浓度值呈显著性的变化 $(P<0.001)$ 测定值与季节之间变化。春季由于青草饲 料中可溶性氮含量较高, 因此春季骆驼奶中的尿素的含量显著地高于其他季节。乳中尿 素的浓度与总氮的浓度呈正相关。然而骆驼奶中尿素的平均浓度低于牛奶。

\section{单峰骆驼 / 双峰骆驼 / 骆驼奶 / 尿素}

Résumé - Variabilité de la concentration en urée dans le lait de chamelle au Kazakhstan. L'urée représente une part de la fraction azotée non-protéique du lait. La variabilité de sa concentration n'a jamais été rapportée dans le lait de chamelle. Dans 102 échantillons de lait de chamelle collectés au Kazakhstan au cours de quatre saisons, dans quatre régions distantes les unes des autres et chez plusieurs espèces (dromadaire, chameau de Bactriane et hybrides), l'urée a été dosée dans le lait cru. La valeur moyenne de la concentration en urée était de $81,6 \pm 60,4 \mathrm{mg} \cdot \mathrm{L}^{-1}$ avec une variation de 0 à $290,5 \mathrm{mg} \cdot \mathrm{L}^{-1}$. Les valeurs variaient significativement $(P<0,001)$ selon la saison, les plus fortes

*Corresponding author (通讯作者): faye@cirad.fr 
concentrations étant observées au printemps au moment où les fourrages contenaient une forte quantité d'azote soluble. L'urée dans le lait était positivement corrélée au taux protéique du lait. Ces valeurs étaient en moyenne plus faibles que dans le lait de vache.

dromadaire / chameau de Bactriane / lait / urée

\section{INTRODUCTION}

The milk contains two main nitrogen fractions, the most important part under protein form (casein and whey protein) and a second part under non-protein form representing $<6 \%$ of total nitrogen content in cow milk. This non-protein nitrogen (NPN) part includes mainly urea $(48 \%$ in cow milk). The remaining NPN fraction is composed of amino acids, creatine, hippuric acid, sometimes ammonia, etc. As for the determination of urea in blood (uremia), the urea concentration in milk gives information on the protein status of the animal. Several authors reported positive correlation between uremia and urea in milk [7, 24]. The urea concentration in blood is generally reflected in the milk at $83-98 \%$ [15].

If the main nitrogen fractions in camel milk were known and well described in the literature $[8,9]$, the NPN fractions were rarely specified and their variability never described [1], contrary to cow milk [7]. In a comprehensive study on the variability of camel milk composition in Kazakhstan, including the two species of large camelids (Camelus dromedarius and Camelus bactrianus) and their hybrids, urea was determined in milk samples all over a year [19].

The present communication aims to give some reference values for urea content in camel milk and to explore some interpretable variation factors.

\section{MATERIALS AND METHODS}

\subsection{Sampling procedure}

To obtain maximum variability, the camel milk was sampled in four different regions at extreme points of Kazakhstan: Almaty, Atyrau, Aralsk and Shymkent (the maximum distance between the various points was $>3500 \mathrm{~km}$ ) and in the four seasons of the year. In total, 102 samples were used for quantitative determination of the urea in camel raw milk (Tab. I). Those samples, collected randomly among lactating females on two private farms per region, comprised Bactrian $(n=47)$, dromedary $(n=34)$, hybrid $(n=7)$ and mixed milk $(n=14)$. Sampling was achieved at the milking time in the morning before starting to pasture. In Kazakhstan, the calving season was short and occurred within $<2$ months. Bactrian camel milk samples originated from different Kazakh types as depending on their geographical location: Uralobokeliki, Kyzylorda and OntustikKazakhstan [20, 26]. Milk samples from dromedary camel came from the Turkmen Arvana breed [5, 25]. Hybrid samples involved F1 or F2 crossbred animals. In all cases, milk was obtained by manual milking and kept frozen at $-20{ }^{\circ} \mathrm{C}$ until analysis.

\subsection{Laboratory analysis}

Urea was analyzed by enzymatic method using kit UV-method (Enzymatic BioAnalysis/Food Analysis, Cat. No. 0542 946, Boehringer-Mannheim distributed by R-Biopharm France). The principle of the dosage was based on the hydrolysis of the urea into ammonia and carbon dioxide by urease. Then, in the presence of glutamate dehydrogenase and NADH, $\mathrm{H}^{+}$ion ammonium gave L-glutamate and $\mathrm{NAD}^{+}$. The disappearance of NADH was measured at 334 or $340 \mathrm{~nm}$. 
Table I. Camel raw milk sampling design by region (Almaty, Atyrau, Aralsk and Shymkent), species and season (W, winter; Sp, spring; Su, summer and A, autumn).

\begin{tabular}{|c|c|c|c|c|c|c|c|c|c|c|c|c|c|c|c|c|}
\hline \multirow[b]{2}{*}{ Breed } & \multicolumn{4}{|c|}{ Almaty $(n=33)$} & \multicolumn{4}{|c|}{ Atyrau $(n=29)$} & \multicolumn{4}{|c|}{ Aralsk $(n=6)$} & \multicolumn{4}{|c|}{ Shymkent $(n=34)$} \\
\hline & W & $\mathrm{Sp}$ & $\mathrm{Su}$ & A & W & $\mathrm{Sp}$ & $\mathrm{Su}$ & A & W & $\mathrm{Sp}$ & $\mathrm{Su}$ & A & W & $\mathrm{Sp}$ & $\mathrm{Su}$ & A \\
\hline Bactrian & 3 & 5 & 4 & 4 & 7 & 2 & 7 & 6 & & & & 1 & & 7 & 1 & \\
\hline Dromedary & 5 & 8 & 3 & 1 & 2 & & 1 & 1 & & 1 & & & 2 & 2 & 2 & 6 \\
\hline Hybrid & & & & & & & & & & 2 & & & 2 & 2 & 1 & \\
\hline Mixed milk & & & & & & 1 & 1 & 1 & & 1 & & 1 & 1 & 6 & 1 & 1 \\
\hline Total & 8 & 13 & 7 & 5 & 9 & 3 & 9 & 8 & 0 & 4 & 0 & 2 & 5 & 17 & 5 & 7 \\
\hline
\end{tabular}

In order to study the correlation with protein content in milk, the total protein content (TPC) was determined: Nitrogen $(\mathrm{N})$ was determined by the Kjeldahl method [16] and the conversion $\mathrm{N} \times 6.38$ was used to quantify the TPC.

The main plants consumed by the camels were sampled in spring and the protein content was also determined by the Kjeldahl method.

\subsection{Statistical analysis}

A linear model was tested for urea concentration as dependent variables. The tested variation factors were the region (Reg), the species (Spec), the season (Seas) and their interactions. The limit of signification level for variance analysis was 0.05 . The results are presented as mean plus/ minus standard error. As the variances were not homogeneous, data were log transformed in order to get normal distribution of the values (log transformation). The correlation between NPN and TPC was tested using Pearson correlation. The software used was XLStat2009.

\section{RESULTS AND DISCUSSION}

The non-protein fraction determination in cow's milk is useful for the cheese industry [15], for assessment of the potential nitrogen pollution by dairy cows [6], as indicator for the reproduction performances control [14] and for assessing feeding strategy of dairy animals [2]. This last point is particularly important in dairy cow farming systems, because the milk urea determination could improve the general metabolic efficiency of the producing animal, but could also help for a better economical management by reducing the protein overfeeding in the diet. However, the use of camel milk is not common in cheese industry, and the contamination risk for environment is low in extensive farming system. Nevertheless, the present trends were dairy intensification in camel farming system which requires a more convenient feeding management. In that context, the determination of milk urea takes a new importance as indicator of protein feeding [18]. Elsewhere, the variability of urea is not referenced in this species.

\subsection{Mean value of urea in camel milk}

On average, in the 102 camel milk samples, the urea concentration was $81.6 \pm 60.4 \mathrm{mg} \cdot \mathrm{L}^{-1}$. Twelve milk samples had no urea. The values were in the range 0-290.5 $\mathrm{mg} \cdot \mathrm{L}^{-1}$. Very few references concerning urea in camel milk were reported in the literature. The concentrations in camel milk generally ranged between 80 and $400 \mathrm{mg} \cdot \mathrm{L}^{-1}$ as well in cow [27] as in goat $[15,21]$ with a recommended average 
Table II. Source of variation (type III) and signification level (test $F$ ) for the urea and ammonia concentration in camel milk from different regions of Kazakhstan at different seasons and for different species.

\begin{tabular}{lccc}
\hline Source of variation & \multicolumn{3}{c}{ Urea } \\
\cline { 2 - 4 } & DOF & $F$ & $\operatorname{Pr}>F$ \\
\hline Region & 3 & 2.691 & 0.053 \\
Season & 3 & $\mathbf{9 . 8 6 6}$ & $<\mathbf{0 . 0 0 0 1}$ \\
Species & 3 & 0.711 & 0.549 \\
Reg $\times$ Seas & 7 & $\mathbf{7 . 6 1 8}$ & $<\mathbf{0 . 0 0 0 1}$ \\
Reg $\times$ Spec & 6 & 1.124 & 0.357 \\
Seas $\times$ Spec & 8 & 1.797 & 0.092 \\
\hline
\end{tabular}

DOF, degree of freedom; Pr, probability.

Bold values are significant.

between 100 and $160 \mathrm{mg} \cdot \mathrm{L}^{-1}$ [2]. On average, our values appeared lower with a range between 0 and $290 \mathrm{mg} \cdot \mathrm{L}^{-1}$ and a median of $80 \mathrm{mg} \cdot \mathrm{L}^{-1}$. The nitrogen metabolism was appreciably different in camel where the urea recycling was quite more important than for other ruminants [22]. According to the distribution of the values in our study, the normal level in camel milk could be considered between 30 and $120 \mathrm{mg} \cdot \mathrm{L}^{-1}$. It is quite surprising to find some zero value in urea concentration in milk as no similar observations were reported in cow or goat milk. Generally, the low urea values in milk were encountered in case of limited availability of degradable nitrogen, but in our samples there was no difference in protein concentration between milk with no urea and milk with urea.

\subsection{Variation factors}

If the variation factors of urea in cow milk were described for long time [17], no data were available for camel milk. The analysis of variance (ANOVA) showed a significant effect of the season (Tab. II) on the urea concentration in milk $(P<0.001)$. The highest value in camel milk urea was observed in spring $\left(111.5 \pm 77.6 \mathrm{mg} \cdot \mathrm{L}^{-1}\right)$ and the lowest in autumn (46.4 \pm $\left.38.0 \mathrm{mg} \cdot \mathrm{L}^{-1}\right)$. No significant difference was observed between species or region. However, a significant interaction Season $x$ Region was reported $(P<0.001)$. The pattern of seasonal change was clearly observed in Shymkent region only. Usually, the main variation factor of urea concentration in milk was the feeding, especially the ratio protein/ energy [4]. A high urea concentration in milk could be caused by an excess of proteins degraded in the rumen or an excess of nondegraded proteins in the gut in relation to the available energy for using them [7]. So, the urea concentration in milk could be used as an indicator of the protein overfeeding [13], better than the total protein. However, a high concentration could also show a severe protein underfeeding leading to an important protein catabolism, as it was observed in blood urea of young camel under severe protein deficiency [10].

No data were available in our study on the feeding system of the animals, but all of them were fed on natural pastures. The pastures were composed mainly of Artemisia sp. (14.6 $\pm 5.2 \%)$, Alhadji Pseudolhadji $(22.7 \pm 3.2 \%)$ and Tamarix sp. $(17.3 \pm 2.8 \%)$, all plants containing relatively high level of protein. However, the quality of the pasture being linked to the season, the relationship with season was not a surprise. Indeed, the nutritive value of the diet, notably the content in soluble nitrogen, was obviously higher in spring at the beginning of the plant growth after winter time. This nutritive value, especially the protein content of the grasses, decreased with the hot season. The lowest mean value was reported in autumn. In winter, the animals could receive some supplements (hay or concentrates) contributing to an increase of the protein in the diet and correlatively of the urea concentration in milk. In dairy cow, some authors reported a significant increasing of urea in milk at the pasture starting time after indoor housing period in winter [23]. Among the milk 


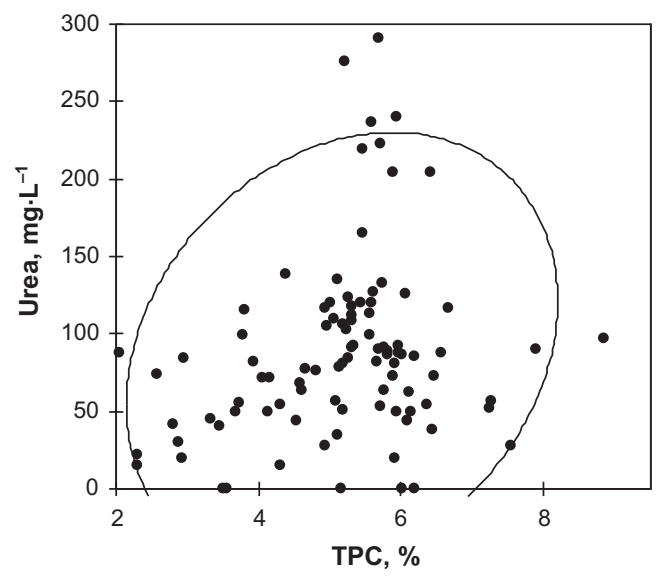

Figure 1. Correlation and variance ellipse (for $2 \mathrm{SD}$ ) between urea concentration in camel milk and total protein in milk in Kazakhstan ( $n=95$; the samples containing no urea were not represented).

samples containing a very high quantity of urea $\left(>130 \mathrm{mg} \cdot \mathrm{L}^{-1}\right), 92 \%$ were collected in spring and $75 \%$ came from Shymkent region where the food supplementation (concentrates rich in soluble nitrogen) at the end of winter was a common practice. The sensitive response to soluble nitrogen supplementation in camel was a common feature already described. In some cases, it could lead to ureic intoxication [11].

This direct relationship between milk urea and season (i.e. nutritive value of the natural diet) could also explain the relationship with the total protein in milk. Indeed, considering the whole sample, urea concentration in milk was positively correlated to total protein concentration (TPC) in milk $(r=0.308 ; \quad P<0.005) \quad$ (Fig. 1). This parameter was under the same influence as urea, and the highest TPC in camel milk was also observed at spring [19]. The seasonal variation of urea in milk could be also explained partially by the lactation stage. In zero-grazing farming system, the urea in cow milk was low at the beginning of the lactation, then increased after one month of lactation, and decreased at the end of lactation [3]. In our study, the calving season occurred in winter (December to February). The spring corresponded to the lactation peak. So, a mixed effect (lactation stage and nutritive value of the diet) could support the observed seasonal effect.

The absence of relationship with the species underlined probably the lack of genetic effect. In dairy cow, the between breed variability was generally lower than the within breed variability [2]. In large camelids, urea did not appear as a discriminant parameter of the milk composition between the species [12].

The regional effect was a combination of feeding and climatic conditions. The significant interaction Season $\times$ Region could be partly attributed to the overlapping between seasonal feeding variation and regional feeding variation.

\section{CONCLUSION}

The NPN fraction (urea) in camel milk represented $<2 \%$ of the nitrogen content in our camel milk samples. On average, the urea content in camel milk appeared lower than in cow. The camel is well known 
for its ability to develop mechanisms of resistance to mineral, energetic or protein underfeeding. The nitrogen recycling is one of these mechanisms, allowing the camel to valorize poor nutritive grasslands. The relative low quantity of urea in milk testifies the ability of camel to limit the urea excretion through the milk. It could be a supplementary asset in the adaptation of camel to the harsh desert conditions. However, in case of food supplementation rich in soluble nitrogen, the quantity of urea can reach high level in milk, reflecting a high level in blood (hyperuremia). In fact, the camel is very sensitive to ureic contamination and the supply in urea, as it is currently proposed for dairy cow, has to be avoided for dairy camel.

Acknowledgments: The study was supported by the French Ministry of Foreign Affairs (ECONET Programme) and by the French Embassy at Almaty (Kazakhstan). We also thank the camel farmers from Kazakhstan where the milk sampling was achieved.

\section{REFERENCES}

[1] Abu-Lehia M., Chemical composition of camel skim milk concentrated by ultracentrifugation, Int. Dairy J. 6 (1996) 741-752.

[2] Block E., Dépatie C., Lefebvre D., Petitclerc D., L'urée du lait : les sources de variation et les implications, in: Proc. Symp. sur les Bovins laitiers, Publ. Conseil des Productions Animales du Québec (CPAQ), Québec, Canada, 1998, pp. 77-87.

[3] Carlsson J., Berström J., Pehrson B., Variations with breed, age, season, yield, stage of lactation and herd in the concentration of urea in bulk milk and individual cow's milk, Acta. Vet. Scand. 36 (1995) 245-254.

[4] Carlsson J., Pehrson B., The influence of the dietary balance between energy and protein in milk concentration. Experimental trials assessed by two different protein evaluation systems, Acta. Vet. Scand. 35 (1994) 193 205.
[5] Cherzekov A., Saparov G., The milk productivity of the camel Arvana breed and its use, in: Faye B., Esenov P. (Eds.), Proceedings of International Workshop Desertification Combat and Food Safety, the Added Value of Camel Producers, Ashkhabad, Turkmenistan, 19-22 April 2004, NATO Sciences Series, Vol. 362, Life and Behavioural Sciences, IOS Press Publisher, Amsterdam, The Netherlands, 2005, pp. 215-220.

[6] Delaby L., Peyraud J.L., Vérité R., Marquis B., Effet de la complémentation protéique sur les performances des vaches laitières au pâturage conduit à 2 niveaux de fertilisation, Ann. Zootech. 44 (1995) 173-188.

[7] DePeters E.J., Ferguson J.D, Non-protein nitrogen and protein distribution in the milk of cows, J. Dairy Sci. 75 (1992) 3192-3209.

[8] El-Hatmi H., Khorchani T., Attia H., Characterization and composition of camel's (Camelus dromedarius) colostrum and milk, Microbiol. Hyg. Alim. 18 (2006) 13-17.

[9] Farah Z., Composition and characteristics of camel milk, J. Dairy Res. 60 (1993) 603-626.

[10] Faye B., Jouany J.P., Chacornac J.P., Ratovonanahary M., L'élevage des grands camélidés. Analyse des initiatives réalisées en France, INRA Prod. Anim. 8 (1995) 3-17.

[11] Faye B., Konuspayeva G., Messad S., Loiseau G., Discriminant milk components of Bactrian camel (Camelus bactrianus), dromedary (Camelus dromedarius) and hybrids, Dairy Sci. Technol. 88 (2008) 607-617.

[12] Faye B., Saint-Martin G., Cherrier R., Ruffa A., The influence of high dietary protein, energy and mineral intake on deficient young camel: I. Changes in metabolic profiles and growth performance, Comp. Bioch. Physiol. 102A (1992) 409-416.

[13] Godden S.M., Lissemore K.D., Kelton D.F., Leslie K.E., Walton J.S., Lumsden J.H., Relationships between milk urea concentration and nutritional management production and economic variables in Ontario dairy herds, J. Dairy Sci. 84 (2001) 1128-1139.

[14] Gustafsson A.H., Carlsson J., Effects of silage quality, protein evaluation systems and reproduction in dairy cows, Livest. Prod. Sci. 37 (1993) 91-105.

[15] Hutjens M.F., Barmore J.A., Milk urea test gives us another tool, Hoards Dairyman 40 (1995) 401. 
[16] ISO8968-1, Milk - Determination of nitrogen content - Part 1: Kjeldahl method, 2001.

[17] Journet M., Vérité R., Vignon B., L'azote non protéique du lait : facteurs de variation, Lait 55 (1975) 212-223.

[18] Juhasz J., Nagy P., Challenges in the development of a large-scale milking system for dromedary camels, in: Nagy P., Huscenicza G. (Eds.), Proceedings of WBC/ ICAR 2008 Satellite Meeting on Camelid Reproduction, Budapest, Hungary, 12-13 July 2008, 84-87.

[19] Konuspayeva G., Variabilité physico-chimique et biochimique du lait des grands camélidés (Camelus bactrianus, Camelus dromedarius et hybrides) au Kazakhstan, Ph.D. in Food sciences, Université Montpellier II, France, 2007.

[20] Konuspayeva G., Faye B., A better knowledge of milk parameters, a preliminary step for improving the camel milk market opportunity in a transition economy. The case of Kazakhstan, in: Kohler-Rolleifson I., Rathore H.S. (Eds.), Proceedings of International Conference on Saving the Camel and Peoples' Livelihood, LPPS Publisher, Sadri, Rajasthan, India, 23-25 November 2004, pp. 28-36.

[21] Martin B., Coulon J.B, Chamba J.F., Bugaud C., Effect of milk urea content on characteristics of matured Reblochon cheeses, Lait 77 (1997) 505-514.

[22] Orskov E.R., Whitelaw F.G., Le recyclage de l'azote dans le tractus gastrointestinal, in: Séminaire sur la digestion, la nutrition et l'alimentation du dromadaire, no. 2, Options méditerranéennes, série séminaires, Ouargla, Algérie, 1989, p. 99.

[23] Refsdal A.O., Baevre L., Bruflot R., Urea concentration in bulk milk as an indicator of the protein supply at the herd level, Acta. Vet. Scand. 26 (1985) 153-163.

[24] Roseler D.K., Ferguson J.D., Sniffen C.J., Herrema J., Dietary protein degradability effects on plasma and milk urea nitrogen in Holstein cows, J. Dairy Sci. 76 (1993) 525534.

[25] Tasov A., Alybaev N., Camel genetic resources and ways of camel breeding products use for population of Kazakhstan arid areas, in: Faye B., Esenov P. (Eds.), Proceedings of International Workshop, Desertification combat and food safety, the added value of camel producers, Ashkhabad, Turkmenistan, April 19-22, 2004, Vol. 362 NATO Sciences Series, Life and Behavioural Amsterdam, The Netherlands, 2005, pp. 121-123.

[26] Terenytev C.M., Camel farming [Verbludov skotovodstvo], Kolos Publisher, Moscow, Russia, 1975.

[27] Vérité R., Rétif S., Faverdin P., Milk urea as an index for nutritive protein balance urinary $\mathrm{N}$ excretion in dairy cows on conserved diets, in: Proceedings of VII Symposium on Protein Metabolism Nutrition, Estaeion Zooteeniea Nacional, Vale de Santazem, 24-27 May 1995, pp. 33-48. 